\title{
Erratum to: Assessment of pathogenic bacteria in water and sediment from a water reservoir under tropical conditions (Lake Ma Vallée), Kinshasa Democratic Republic of Congo
}

\author{
Paola M. Mwanamoki • Naresh Devarajan • Florian Thevenon • \\ Emmanuel K. Atibu • Joseph B. Tshibanda • Patience Ngelinkoto • Pius T. Mpiana • \\ Kandasamy Prabakar • Josué I. Mubedi • Christophe G. Kabele • Walter Wildi • \\ John Poté
}

Published online: 5 August 2014

(C) Springer International Publishing Switzerland 2014

\section{Erratum to: Environ Monit Assess}

DOI: 10.1007/s10661-014-3891-6

The original version of this article unfortunately contained a mistake. The publication year and volume for reference Varga, L. was incorrect. The correct reference is presented below.

Varga, L. (2011). Bacteriological quality of bottled natural mineral waters commercialized in Hungary. Food Control, 22, 591-595.

The online version of the original article can be found at http://dx. doi.org/10.1007/s10661-014-3891-6.

P. M. Mwanamoki • C. G. Kabele

Section Nutrition diététique, Institut Supérieur des Techniques Médicales/Kinshasa,

B.P. 774, Kinshasa XI, Democratic Republic of Congo

N. Devarajan $\cdot$ F. Thevenon $\cdot$ W. Wildi $\cdot$ J. Poté $(\bowtie)$

Faculty of science, Forel Institute and Institute of

Environmental Sciences, University of Geneva,

CP 416, 1290 Versoix, Switzerland

e-mail: john.pote@unige.ch

N. Devarajan $\cdot$ K. Prabakar

Postgraduate and Research Department of Zoology, Jamal

Mohamed College,

Tiruchirappalli 620020 Tamil Nadu, India
E. K. Atibu • J. B. Tshibanda • P. T. Mpiana · J. Poté Department of Chemistry, Faculty of Science, University of Kinshasa (UNIKIN),

B.P. 190, Kinshasa XI, Democratic Republic of Congo

P. Ngelinkoto $\cdot$ J. I. Mubedi $\cdot$ J. Poté

Université Pédagogique Nationale (UPN),

Croisement Route de Matadi et Avenue de la Libération. Quartier Binza/UPN, B.P. 8815, Kinshasa, Democratic Republic of Congo 